\title{
解説記事
}

\section{GISの標準コアカリキュラムと知識体系を踏まえた 実習用オープン教材の開発と評価}

Development and Evaluation of Open-Access e-Learning Materials for GIS Education Based on the Existing Core Curriculum and Body of Knowledge

\section{山内＼cjkstart啓之・小口＼cjkstart高・早川＼cjkstart裕式・瀬戸＼cjkstart寿一}

YAMAUCHI Hiroyuki, OGUCHI Takashi, HAYAKAWA Yuichi S. and SETO Toshikazu

\author{
（2019年4月9日受付 2019年5月27日受理）
}

\begin{abstract}
筆者らは，大学の学部や大学院の GIS の実習授業を充実させるための教材を開発し，オープンな活用ができるコ ンテンッとして広く公開するためのプロジェクトを実施している，教材は，既存プロジェクトの成果である書籍 『地理情報科学GIS スタンダード』と対応するように構成した，GISを用いたデータの処理には，フリーかつオー プンソースのソフトウェアを利用した。これらの教材は，GIS実習の課題や使用するソフトウェアの特性を考慮 し，二次利用しやすいようにオープンライセンスのパッケージとして整備し，GitHubを用いて試験公開を行って いる. 本稿では, 開発中の教材の設計と初期の構築の経緯をまとめ, 既存の GIS教材との比較を行い, 本教材の有 用性について評価した結果を解説する。
\end{abstract}

We have been conducting a project on the "Development of Open-Access e-Learning Materials for GIS Education Based on the Existing Core Curriculum and the Body of Knowledge.” This project aims to develop and publish online GIS materials for GIS exercises in higher education. The materials were compiled following a textbook of GIS standards published in a past project, mainly using free software. The educational resource package of the materials is provided on the GitHub platform with an open license to enable secondary use. Here we report the process of developing the materials and discuss their advantages in comparison with existing GIS learning materials.

キーワード：GIS教育，実習教材，オープンアクセス，フリー\&オープンソース GIS (FOSS4G), GitHub Key words: GIS education, exercise material, open access, free and open-source GIS, GitHub

\section{I はじめに}

GIS（Geographic Information Systems）の教育を通じ た人材育成は, 地理学の社会貢献として重要である. GIS を活用できる人材を育成するためには，実際にソ フトウェアを操作して地図の作成や空間解析を行う実 習形式の教育が必要である。欧米では1980年代に GIS が急速に発展し, 地理学にも積極的に導入されたが, 日本での導入は遅れた（岡部 1989）。この遅れは今日 までにかなり解消されたが, 全国の大学の地理学教室 や関連学科における GIS 教育の量と質が十分ではない ことも指摘されてきた（佐々木ほか 2008）.

このような状況を踏まえて, 日本の地理学関係の研 究者は, 大学や大学院における GIS 教育を充実させる ために, 科学研究費補助金による複数の研究プロジェ
クトを行ってきた. たとえば, 基盤研究 (A)「地理 情報科学標準カリキュラム・コンテンツの持続協働型 ウェブ・ライブラリーの開発研究」(平成 $17 \sim 19$ 年 度, 代表者：岡部篤行）, 基盤研究（A）「地理情報科 学の教授法の確立一大学でいかに効果的に GIS を教え るか一」(平成 $17 \sim 20$ 年度, 代表者：村山祐司)，基 盤研究（A）「地理情報科学標準カリキュラムに基づ く地理空間的思考の教育方法・教材開発研究」(平成 $21 \sim 25$ 年度, 代表者：浅見泰司）が挙げられる.こ れらのプロジェクトによって, GISのコアカリキュラ ムやそれを基礎とした地理情報科学の知識体系の編纂 が行われ，それらを講義用教材として編集した書籍 『地理情報科学 GIS スタンダード』（浅見ほか編 2015. 以下，「GIS スタンダード」と記す）の出版やWEBを 通じた講義用資料の公開が行われた。 
上記のプロジェクトでは，講義用の教材や資料の整 備が主な目的であったが，実習授業に関する検討も一 部で行われた。たとえば，高橋・岡部（2008a）は， GIS 実習のためのオンライン教材の開発とそれを用い た授業実践について報告した。高橋・岡部（2008b， 2010）は, 開発したオンライン教材を用いて, 学習者 の類型化や学習効果を規定する要因を検討した．渡辺 （2008）は，独学でも GISが学習できる e-learning教材 を構築し，それを用いた授業実践と学習状況の調査を した，村山・駒木（2006）は，空間統計に特化した無 償（フリー）のGISソフトウェアを開発し，実習利用 例を紹介した．しかしながら，これらの事例はGISの コアカリキュラムと部分的に対応した実習用教材の整 備にとどまっており，コアカリキュラムを網羅的に反 映する教材の整備には至っていなかった.

そこで筆者らは，既存プロジェクトにおける体系的 な成果である「GIS スタンダード」と対応した高等教 育向けの GIS の実習用教材を開発するプロジェクトを 進めている（科学研究費基盤研究 (A)「GIS の標準コ アカリキュラムと知識体系を踏まえた実習用オープン 教材の開発」, 平成 $27 \sim 31$ 年度, 代表者：小口 高. 以下，本プロジェクトとする)。本プロジェクトでは， 近年フリーかつオープンソースの GIS ソフトウェアを 活用した教育が，世界的に普及しつつある現状を考慮 し，その流れに沿った実習用教材を整備した。また， 整備した教材を用いた実習授業も行い，本教材の難易 度の調查や，受講者の意見をもとに教材を改良した。 本稿では, 開発した教材の設計と初期の構築の経緯を まとめ, 実習授業での利用結果を踏まえて, 既存の GIS 教材と比較し, 本教材の有用性について評価した 結果を解説する.

\section{IIオンライン教材の構築手法}

\section{1. 教材のシステム設計}

地理学教室における GIS の実習授業では，幅広い空 間解析機能と世界的なシェアを持つ商用 (有償) のソ フトウェアであるESRI社の ArcGISが用いられること が多かった．高橋・岡部（2008a）や渡辺（2008）も， ArcGISの使用法を解説した学習サイトの構築や授業 の実践を行っている。一方で，教員養成系大学と地理
学系の学部のシラバスを分析し，GIS教育の現状をま とめた矢部・橋本（2016）は，フリーのGISソフト ウェアであるMANDARAの利用率をとりあげ，有償 GIS のコストとフリー・ソフトウェアの活用について 議論した。最近では，世界中にいるプログラム開発者 が主にWEBを通じて持続的に保守管理しているオー プンソースのソフトウェアを用いた教育や教材が増え つつある，たとえば，オープンソースの地理情報技術 の開発や共有を行うコミュニティを支援している OSGeo財団（The Open Source Geospatial Foundation） は，フリー\&オープンソースの GIS の総称である FOSS4G（Free and Open Source Software for Geospatial）を 用いて，世界中で平等に地理空間情報に関する教育や 学習が可能となるような社会的な取組み (GeoForAll) を行っている。この一環として, FOSS4G GeoAcademy Curriculum ${ }^{1)}$ のような FOSS4G の利用方法を解説し たオンライン学習サイトも運営されている. 国内でも OSGeo 財団日本支部が中心となり, FOSS4G の利用方 法を日本語で解説したマニュアルや資料を整備してい る2。.また，大野ほか（2006）や岩崎ほか（2014） は，学習管理機能を有するGISのオンライン学習サイ 卜を構築した.

以上の動向を踏まえて, 本プロジェクトでは, FOSS4G の GIS ソフトウェアを積極的に活用して教材 を構成することにした，中でも国内で多くの利用例 （たとえば青山 2016，薄井ほか 2017）や資料があり， 多様なプラグインが利用できるQGISを主に利用し た，QGISは，有償のGIS と比べてバージョン更新の 頻度が高いため，本教材では 1 年間のバグ更新が保証 された長期リリースバージョン 2.8 を採用した。たた LQGISのみでは実習が難しい場合もあるため, GRASS GIS, PostGIS, SAGA GIS等のフリー\&オープ ンソースソフトウェアや，オープンソースではないが フリーで使用できるSAM（Spatial Analysis in Macroecology）等のソフトウェアも適宜利用した。本プロ ジェクトでは，文系理系を問わないGIS の実習用教材 を提供するために，プログラミングの知識が必要なソ フトウェアの使用は最小限とし， マウスの操作で扱え る内容を優先した。ソフトウェアと同様に実習に使用 したデータも，基盤地図情報や国土数值情報のように 無償で利用できるものを用いた．また，地方公共団体 
のオープンデータのように，ライセンス上再配布や改 変が可能なものは, 実習用データに加工して提供し た。

最近の高等教育におけるオープンエデュケーション では, MOOC（Massive Open Online Course）のような 講義を撮影した動画を主体とするオンライン教材の開 発と提供が積極的に行われている。一方, 本プロジェ クトで開発した教材は実習授業での活用を想定してい るため, 多様な環境や学習対象に応じて教材の改変や 補足が容易にできるように，電子テキストとして設計 した．教材はHTMLに変換可能なテキストファイル をいくつかの記号を組み合わせて簡易的に記述する Markdownの形式で構築した. GISの基本操作はマウ スを用いたものが多いため，操作を解説した図を多用 して直観的に理解できる教材となるように工夫した。

GISの実習では，ソフトウェアの活用法だけでな く, 地理情報科学の理論や空間デー夕の構造も理解す る必要がある。一方で, これらを実習の内容と併記す ると, 教材が複雑化して利用者の混乱や学習意欲の低 下に繋がる恐れがある。 また，教材が複雑化すると， ソフトウェアやプラグインのバージョン更新に伴う教 材の変更に要する負担も大きくなると予想された。 そ こで，既存のプロジェクトで整備された GIS やデータ 処理の概念に関する教材を参照できるようにリンクづ けし，本教材内での解説はソフトウェアの操作に関わ るものを主体とした。また，ベクタデータとラスタ データの違いのような初学者が躓きやすいGIS 特有の 学習項目については，わかりやすく丁寧な解説を試 み，必要に応じて概念図を挿入した。ささらに，学習を 補助するための用語集やエラー集も作成し，効率的な 学習ができるように工夫した。

上記したコアカリキュラムに対応した教材の内容を 補足するような副教材も整備した，具体的には，野外 調查によって空間データを取得するための機材の活用 法を解説した教材や，インターネットで空間データを 公開する手法を解説した教材を整備した。

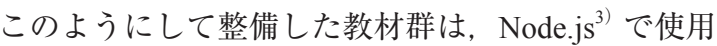
できる GitBookライブラリを用いて視認性を高めるこ とを目的に，電子書籍のようなスタイルで閲覧できる ようにした (図1)。また, プロジェクトの概要や教 材のソースコードを参照できるページも作成した．以

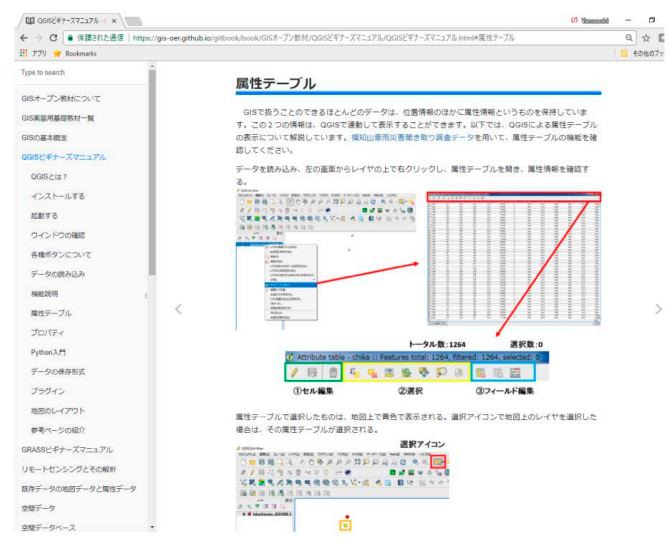

図 1 教材のインターフェース

Fig. 1 Interface of the materials (https://gis-oer.github.io/gitbook/book/)

上で述ベたコンテンツを, GIS Open Educational Resources（GIS-OER）としてパッケージ化し，利用者の 用途に適した提供手法とライセンスに関する検討を 行った後に試験公開した。

\section{2. 教材の提供手法}

国外では，マサチューセッツ工科大学によるMIT Open Course Ware $の$ Geographic Information System (GIS) Tutorial $^{4)}$ や，ノースカロライナ州立大学による NCSU GeoForAll lab ${ }^{5)}$ のように，幅広い利活用を想定 して教材と閲覧のための設計ファイルをまとめたパッ ケージをオープンなライセンスで提供する事例があ る. 本教材でも教材のパッケージ化とオープンライセ ンスの適用を行った。 パッケージを運用するプラット フォームにはGitHubを採用した。 GitHubは, ソース コードのバージョン管理システムの Gitを用いたWEB サービスであり，ソフトウェアの開発チームやその支 援者が協力してコンテンツの整備を行うための機能を 持つ。たとえば, GitHubにおけるコミュニケーショ ンツールであるIssues 機能, 改善案を送信するPull Request機能，コンテンツ制作のためのタスク管理が できるProjects機能，リポジトリの複製ができる Fork およびClone機能，コンテンツを静的な WEBページ にホスティングする GitHub Pagesがある. GitHubで は，ファイルの保管場所であるリポジトリをWEB上 に作成できる，本プロジェクトでは，開発したコンテ ンツを用途ごとにリポジトリに格納した。たとえば, 教材の補足や修正といった編集に必要な教材のソース 
コードであるMarkdownファイル群と，教材の閲覧に 適したHTMLファイル群は, 別のリポジトリとして 提供した。

開発した教材パッケージには，誰もが自由に利活用 できるようにクリエイティブ・コモンズに基づく CCBY-SA（表示-継承）4.0国際ライセンスを付与した. 利用者は，出典の表記をライセンスと同じものとする ことを条件に，教材の複製，改変を伴う二次利用，お よび再配布が可能である.

\section{3. 教材のコンテンツ構築}

教材の学習項目は, 前記の書籍「GISスタンダー ド」のうち，実習が可能な内容を含む 6 ～23章およ び26章と対応するように構成した。表1は，「GIS ス タンダード」の章ごとに, 教材の学習レベルと教材 名, 空間データの処理に用いたソフトウェアを示した ものである，学習レベルは，大学の地理学教室で実施 されているGIS実習のシラバスの構成等を参考に, 「入門」「基礎」「応用」の3つのレベルに区分した.

入門レベルの教材は,「GIS スタンダード」の 22 章 と 23 章と対応し, GIS の基本的な操作手法であるデー 夕の読み込み, 重ね合わせ, ビジュアライズ, 地図の レイアウト等を解説している，基礎レベルの教材は,
ベクタデータやラスタデータを用いたさまざまな空間 解析の手法, 空間データの管理手法, 空間データの入 手方法を解説しており，「GISスタンダード」の 6 〜 15 章, 21 章, 26 章と対応する. 応用レベルの教材は, 空間的自己相関や空間補間のような, 空間統計学と関 連性の高いデー夕処理を解説したものであり，「GIS スタンダード」の16〜20章と対応する.

GIS の操作方法はソフトウェアによって大きく異な る。本教材で対象となるデー夕処理には, 既述の通り 主にQGISをソフトウェアとして用いたが，QGISの 主要機能を用いるのみでは処理が難しい場合や, QGISのプラグインがない空間統計学的な処理を行う 場合には, CrimeStat, GeoDa, SAGA GIS, R, SAM等の ソフトウェアも併用することとした，ただし，基礎的 操作である入門レベルについては，本教材の全体を通 じて利用頻度が高いQGIS と GRASS GISのみを用い た.

教材では, GIS ソフトウェアの操作法を解説するの みならず，入門レベルと基礎レベルの教材を中心に理 解度の向上を目的とした学習課題を設定し, 受講者が 学習を深められるように工夫した。また，大学の実習 授業で利用しやすいように，各教材を組み合わせて， 集中授業向け $(1 \sim 2$ コマ分), 四半期分（6コマ）,

表 1 室内における GIS ソフトウェア活用の教材の特徵と「GIS スタンダード」との対応 Table 1 Major sections related to the GIS core curriculum and features of materials

\begin{tabular}{|c|c|c|c|}
\hline 学習レベル & 教材名 & 主なソフトウェア & 「GIS スタンダード」の章との対応 \\
\hline \multirow[t]{2}{*}{ 入門 } & QGIS ビギナーズマニュアル & QGIS & 22,23 \\
\hline & GRASS GIS ビギナーズマニュアル & GRASS GIS & \\
\hline \multirow[t]{12}{*}{ 基礎 } & リモートセンシングとその解析 & MultiSpec, QGIS & 6 \\
\hline & 既存データの地図データと属性データ & WEB ブラウザ & 7 \\
\hline & 空間データ ～～～～～～～～～ & QGIS & 8 \\
\hline & 空間データベース & PostGIS, QGIS & 9 \\
\hline & 空間データの結合・修正 & QGIS & 10 \\
\hline & 基本的な空間解析 & QGIS & 11 \\
\hline & ネットワーク分析 & GRASS GIS, QGIS & 12 \\
\hline & 領域分析 ～～～～～～～～～～～ & QGIS & 13 \\
\hline & 点データの分析 & QGIS, CrimeStat & 14 \\
\hline & ラスタデータの分析 & QGIS, GRASS GIS & 15 \\
\hline & 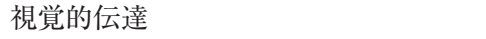 & QGIS & 21 \\
\hline & 参加型 GIS と社会貢献 & OpenStreetMap & 26 \\
\hline \multirow[t]{5}{*}{ 応用 } & 傾向面分析 & SAM & 16 \\
\hline & 空間的自己相関 & CrimeStat & 17 \\
\hline & 空間補間 & QGIS, GRASS GIS, SAGA GIS & 18 \\
\hline & 空間相関分析 & $\mathrm{R}, \mathrm{SAM}$ & 19 \\
\hline & 空間分析におけるスケール & GeoDa & 20 \\
\hline
\end{tabular}


半期分（14コマ）の授業案も作成した．1〜2コマを 想定した集中授業向けの授業案では，短期間でGISを 用いたデータ処理が体験できるように「GIS スタン ダード」の 22,23 章と 15 章の内容を部分的に取り出 し，再構成した教材を整備した。四半期分と半期分の 授業案は, 各教材のコマ数に応じた利用を想定し, 教 材の学習の順番を指示するページを整備した.

\section{III 大学のGIS 実習における本教材の利用}

\section{GIS 実習の概要}

本教材を用いた最初の具体的な実践として，東京大 学理学部地球惑星環境学科での授業の一部で実習を 行った，実習を含む授業は2016年9月22日から 11 月 10 日の期間に 6 回行われた。受講者の大半は, 事前に

表2 実習授業の構成

Table 2 Constitution of GIS exercise class

\begin{tabular}{|c|c|}
\hline 第 1 回 & $\begin{array}{l}\cdot \text { QGIS ビギナーズマニュアル } \\
\cdot \text { 任意課題：GRASS GIS ビギナーズマニュアル }\end{array}$ \\
\hline 第2 回 & $\begin{array}{l}\text { ·既存の地図データと属性データ } \\
\text { ·空間データ (空間座標系の変換, ジオリファレ } \\
\text { ンス等 })\end{array}$ \\
\hline 第3 回 & $\begin{array}{l}\cdot \text { 空間デー夕の結合・修正 } \\
\cdot \text { 視覚的伝達 (属性值の分類等 })\end{array}$ \\
\hline 第 4 回 & $\begin{array}{l}\text { ·基本的な空間解析（ディゾルブ，クリップ等） } \\
\text { •ネットワーク分析（最短経路検索） }\end{array}$ \\
\hline 第 5 回 & $\begin{array}{l}\text { ·点データの分析（メッシュ集計, カーネル密度 } \\
\text { 推定等) } \\
\text { ·領域分析 }\end{array}$ \\
\hline 第6回 & $\begin{array}{l}\text { · ラスタデータの分析 } \\
\text { ·空間補間 (不整形三角網, 逆距離加重平均法) }\end{array}$ \\
\hline
\end{tabular}

はGISの操作を未経験だった学部 3 年生であった。授 業は 3 限から 5 限の 3 コマ連続（1コマは，105分）で 行われ，1コマ目ではGISに関する講義を行い，残り の2コマで実習を行った，実習では本教材を活用し， 表2のように構成した，実習の冒頭では課題の簡単な 説明をし，次に受講者が教材を参考にしつつ, 一人に つき一台用意されたパソコンを用いて作業を進めた。 各実習の最後には，学習内容と対応した地図の作成 と, いくつかの設問への回答を課題とした．地図の作 成枚数は実習の項目によって異なるが，平均で $3 \sim 4$ 枚であった。

各回の実習の終了後には, 教材の難易度や改良点等 を回答するアンケートを実施した。その結果をもとに 次回に使用する教材を改良した。教材の改良作業は, GitHubを通じて教員とTAが行った。実習中のトラブ ル等に応じて, リアルタイムに教材の補足を行うこと もあった，改良には解説の補足や図の視認性の向上が 含まれる，授業の最終日には，全ての実習を通した教 材と実習の難易度や，教材の改良の効果などを 5 段階 で評価するアンケートを実施した。さらに自由記述欄 も用意し，幅広い意見を収集した。

\section{2. アンケート調査の結果}

全ての実習に継続して参加した15名のアンケート を集計した結果を紹介する（表3）。「a. 全ての実習を 通した教材および実習の難易度」の項目では，受講者 の 6 人が「普通」, 9 人が「難しい」と評価した.「b. 全ての実習を通した教材改良に関する評価」の項目で は，受講者の 10 人が「わかりやすくなった」，5人が

表3 アンケート調査の結果

Table 3 Results of a questionnaire survey

a. 全ての実習を通した教材および実習の難易度

\begin{tabular}{ccccc}
\hline 1. とても易しい & 2. 易しい & 3. 普通 & 4. 難しい & 5. とても難しい \\
\hline 0 & 0 & 6 & 9 & 0 \\
\hline
\end{tabular}

b. 全ての実習を通した教材改良に関する評価

\begin{tabular}{ccccc}
\hline $\begin{array}{c}\text { 1. とても分かりやすく } \\
\text { なった }\end{array}$ & $\begin{array}{c}\text { 2. わかりやすく } \\
\text { なった }\end{array}$ & $\begin{array}{c}\text { 3. どちらとも } \\
\text { いえない }\end{array}$ & $\begin{array}{c}4 . \text { わわりにくく } \\
\text { なった }\end{array}$ & $\begin{array}{c}5 . \text { とも分かりにくく } \\
\text { なった }\end{array}$ \\
\hline 0 & 10 & 5 & 0 & 0
\end{tabular}

注：值は票数を示す.

Note: The values show number of votes. 
「どちらともいえない」と評価した．

自由記述では，「基礎的な操作についての解説が不 足」「間違いやすい箇所についての補足説明が必要」 「操作を解説した図の一部が小さく読み取りづらい」 等の回答を得た．受講者の意見を踏まえた教材改良に ついては,「教材がだんだんわかりやすくなった」等 の回答を得た.

\section{IV運用状況を踏まえた本教材の評価}

\section{1. 実習内容の評価}

本実習の授業は，高橋・岡部 (2008a), 高橋・岡部 （2010），青山（2016）, 薄井ほか（2017）の先行事例 に比べて1コマあたりの内容が多かった。しかしIIIで 述べたように，実習の 4 割の受講者は難易度を「普 通」と評価した。この結果は, 内容が多くても難しさ をあまり感じずに学習できた受講者がいたことを示 す。一方で，6割の受講者は難易度を「難しい」と し，受講者によって評価が分かれた，高橋・岡部 （2008b）は，オンライン教材を用いた GIS 実習の受講 者の学習進度には大きな差があり, オンライン学習へ のなじみやすさ等によって受講者の評価が変わると指 摘した，本実習で用いた教材についても，事前の知識 量やパソコン操作への慣れといった個人差が, 受講者 の評価に影響したと考えられる.

アンケートでは実習教材の解説のわかりにくさが多 く指摘された，上記した個人差に加え，この問題が受 講生に難しさを感じさせる要因となった可能性があ る. 解説のわかりにくさに関する指摘は, 解説文の不 足と使用した図の視認性の悪さに大別できる，前者に ついては, 学習の入門段階でのソフトウェアの操作や データ形式の理解の際に受講者が難しさを感じる傾向 があった，GISの操作に慣れた段階でも，空間座標系 の変換といったGISに特有のデー夕処理の際に, 受講 者が解説文の不足を感じる傾向があった。 これらの点 を考慮して，教材の解説文の充実度を高めることが重 要と考えられる。たとえば，誤った操作をしやすい処 理について，正誤の事例を併記するといった工夫が必 要である.

後者の図の視認性の問題は, 図が小さいために処理 の手順や使用するパラメータの值が読み取りにくいと
いう指摘である，GISの操作はマウスを用いたものが 多いため, コンピュータの画面をキャプチャした画像 を解説に用いることが有用である。 その表示の大きさ を最適化することが，学習を効率的に行うために重要 と判明した，画面をキャプチャした図を用いる際に， 画面全体ではなく対象の箇所のみをトリミングした上 で拡大した図を用いるといった対応が必要である。

\section{2. 教材の管理および提供手法の評価}

QGISを用いて実習授業を行った薄井ほか（2017） は, 担当教員が直面する課題として, 授業用の操作マ ニュアルの更新を指摘している。 QGISに限らずGIS の実習用教材は，定期的な更新が必要であるが，その 負担は授業の担当者や教材の作成者に集中していた. 一方，本教材ではGitHubを教材の管理と提供の基盤 としているため, IIIで述べたような複数人による教 材の改良が可能である，また，第三者による改良案の 提示を行う機能も有している．実際に本プロジェクト では，GitHubのリポジトリを通じて，第三者から教 材の管理手法や，ライセンスの表記法に関する提案も なされている。したがって本教材は，教員の連携によ る授業前後の迅速な教材の改良や，ソーシャルコー ディングによる持続的な教材の管理の可能性を示す実 例となっている.

近年, GISの教材をクリエイティブ・コモンズに代 表されるオープンライセンスで提供することにより， 幅広い活用を目指した事例がある（たとえば，GIT$\mathrm{TA}^{6)}$, GIS Commons ${ }^{7)}$, Datapolitan ${ }^{8)}$ )。本教材もクリ エイティブ・コモンズに基づいたオープンライセンス で提供されており，受講する学生の専攻などに応じ て，自由に内容を補足・改変できるという柔軟性を有 している.

\section{V まとめと今後の展開}

本稿では, フリーかつオープンソースのソフトウェ アを活用し，「GISスタンダード」とも対応したGIS の実習用教材を紹介した．また，授業での利用例と受 講者の評価結果を解説した。本教材は, 誰もが自由に 利活用できるようにクリエイティブ・コモンズに基づ くライセンスを付与し, GitHubを用いて試験提供し 
ている. 本教材の主な特色は，1）フリーかつオープ ンソースの GISソフトウェアを複数活用，2）大学の 授業に対応した体系的な内容，3）複数人による持続 的な教材の保守管理，4）オープンライセンスに基づ いた多様な目的での利活用の可能性の 4 点である。一 方，実習の授業で本教材を利用するために解決すべき 課題もあり, 教材の解説文の充実や, 操作を解説した 図の視認性の向上といった改良が必要である。これら は受講者が躓きやすいソフトウェアの操作やデータ処 理において，特に重要である。

本教材の持続的な発展のためには, 上記のような教 材の改良とともに，教材の保守管理や改良についてオ ンラインで対応ができる協力者を募ることも重要であ る，後者をどのように実現するかについても，今後検 討していく予定である。

\section{謝 辞}

本研究は，科学研究費補助金基盤研究（A）「GIS の 標準コアカリキュラムと知識体系を踏まえた実習用 オープン教材の開発（課題番号：15H01782）」（研究 代表者：小口 高）による成果の一部である.

\section{注}

1) http://spatialquerylab.com/foss4g-academy-curriculum/ （最終閲覧：2019年4月 8 日）

2）たとえば，OSGeo財団日本支部が提供する資料 として「QGISセミナー初級・基礎編（V2.4）」が ある.（https://www.slideshare.net/wata909/qgis（最 終閲覧日：2019年4月 8日))

3） Node.jsは，サーバーサイドで動作する JavaScript の実行環境である。

4) https://ocw.mit.edu/resources/res-str-001-geographicinformation-system-gis-tutorial-january-iap-2016/index. htm（最終閲覧：2019年4月 8日）

5）https://geospatial.ncsu.edu/osgeorel/（最終閲覧日：2019 年4月 8 日）

6） http://www.gitta.info/website/en/html/index.html（最 終閲覧日：2019年4月 8 日) 7）http://giscommons.org/ (最終閲覧日：2019年4月 8日)

8）http://www.datapolitan.com/（最終閲覧日：2019年 4 月 8 日)

\section{文 献}

青山雅史 2016. 教員養成系学部の地理学実習科目へ の GIS 導入の効果と課題——群馬大学教育学部社会 専攻「地理学実習」における実践報告. 群馬大学 教育実践研究 33:1-8.

浅見泰司・矢野桂司・貞広幸雄・湯田ミノリ編 2015 . 『地理情報科学 GIS スタンダード』古今書院.

岩崎亘典 - 森 亮 - 平敷兼貴 - 嘉山陽一 - 古橋大地 升本眞二・米澤 豪・吉田大介・ラガワン ベンカ テェッシュ 2014. FOSS4Gを活用した衛星利用と環 境劣化評価のためのキャパシティビルディング。日 本地球惑星科学連合大会 2014年大会予稿 HTT07-07.

薄井宏行・樋野公宏・真鍋陸太郎 2017. GIS 操作法の 教育の現状と課題——東京大学工学部都市工学科の 演習におけるArcGIS と QGIS の同時教育を通じて. 第26回地理情報システム学会講演論文集 (CDROM) 26: A-3-1.

大野翠子・ベンカテッシュ ラガワン・升本眞二・中 野秀男 2006. Moodle CMS を用いたGIS教育のため のeラーニングコンテンッの開発。情報地質 17 : $128-129$.

岡部篤行 1989. 空間情報科学の曙. 写真とリモート センシング $37(3): 1$.

佐々木緑・小口高・貞広幸雄・岡部篤行 2008. 日 本の大学における GIS教育の調査：地理学関係学 科・専攻の事例. GIS- 理論と応用 16:131-136.

高橋昭子・岡部篤行 2008a. GIS ソフトウェア実習の オンライン学習教材の開発と授業実践. GIS- 理論 と応用 16: 49-85.

高橋昭子・岡部篤行 2008b. オンライン学習教材を用 いた GIS 実習における学習者の類型化とその特徵. 地学雑誌 117: 354-369.

高橋昭子・岡部篤行 2010.オンライン教材による GIS 実習の学習効果を高める要因の分析とそれに基づく 授業改善. GIS-理論と応用 18: 29-38.

村山祐司・駒木伸比古 2006. 空間データ分析マシン （SDAM）を活用した計量地理学の講義と実習. 筑 波大学人文地理学研究 30: 99-112.

矢部直人・橋本暁子 2016. 教員養成系大学・学部に おけるシラバスからみた GIS 教育の現状．兵庫教育 大学大学院連合学校教育学研究科教育実践学論集 17: 213-218.

渡辺 俊 2008. GIS 教育のためのE-learning システム の開発. 地理情報システム学会平成 20 年度研究発 表大会梗概集 17: 513-518. 
E-journal GEO 2019 Vol. 14(2)

〈著者略歴〉

山内 啓之（やまうち ひろゆき）

現在 東京大学空間情報科学研究センター 特任研究員.

小口 高（おぐち たかし）

現在 東京大学空間情報科学研究センター 教授.

早川 裕式（はやかわ ゆういち）

現在 北海道大学地球環境科学研究院 准教授.

瀬戸 寿一（せと としかず）

現在 東京大学空間情報科学研究センター 特任講師. 